\title{
Comparative Evaluation of the Anti-bacterial Efficacy of Herbal Medicaments and Synthetic Medicaments Against Enterococcus faecalis using Real-time Polymerase Chain Reaction
}

\author{
Rajeswari Kalaiselvam ${ }^{1}$, Karthick Soundararajan ${ }^{1}$, Mathan Rajan R ${ }^{1}$, Kandaswamy Deivanayagam $^{1}$, \\ Chakravarthy Arumugam ${ }^{1}$, Arathi Ganesh ${ }^{1}$ \\ 1. Conservative Dentistry and Endodontics, Faculty of Dental Sciences, Sri Ramachandra University, Chennai, IND
}

Corresponding author: Karthick Soundararajan, endokarthick@gmail.com

\begin{abstract}
Periradicular bacterial infections are the proven cause of the failure of endodontic treatment. When the pulp canal gets infected or becomes necrotic, bacterial growth takes place in the form of biofilms and aggregates. During the endodontic procedure, bacterial colonies are disrupted, and the microbial load is reduced by biomechanical preparation, cleaning with anti-microbial solutions, and placing anti-bacterial medicaments in the root canal. These anti-microbial substances are synthetic, having a cytotoxicity effect. In recent times, herbal medicines are an alternative medicine being used increasingly as an intra-canal medicament to fight or prevent common endodontic infections.
\end{abstract}

\section{Aim}

The objective of this study is to compare the anti-bacterial efficacy of herbal medicaments and synthetic medicaments against Enterococcus faecalis (E. faecalis).

\section{Materials and methods}

This was an in-vitro study in which a total of 60 teeth specimens $(n=60)$ were inoculated with E. faecalis for 21 days. Specimens were divided into six groups (Group 1: Piper nigrum (Piperaceae); Group 2: Piper longum (Piperaceae); Group 3: Zingiber officinale Roscoe (Zingiberaceae); Group 4: Calcium hydroxide; Group 5: 2\% chlorhexidine gel (CHX); and Group 6: saline (negative control). The intra-canal medicaments were packed inside the tooth. After five days, the remaining microbial load was determined by using real-time PCR.

\section{Results}

The threshold cycle (Ct) values of Piper nigrum, Piper longum, dried ginger extract, $2 \% \mathrm{CHX}$, calcium hydroxide, and saline were found to be $21.36,20.55,22.14,22.51,23.62$, and 17.81 , respectively. The

Received 07/13/2019

Review began 07/18/2019

Review ended 07/21/2019

Published 07/24/2019

\section{() Copyright 2019}

Kalaiselvam et al. This is an open access article distributed under the terms of the Creative Commons Attribution License CC-BY 3.0., which permits unrestricted use, distribution, and reproduction in any medium, provided the original author and source are credited. obtained mean bacterial load of these products was $8.64,12.52,7.23,0.82,0.14$, and 149.49, respectively.

\section{Conclusion}

Two percent CHX showed high antibacterial activity against E. faecalis followed by calcium hydroxide, Zingiber officinale Roscoe, Piper nigrum, Piper longum, and saline.

Categories: Miscellaneous

Keywords: herbal medicaments, synthetic medicaments, enterococcus faecalis, real-time polymerase chain reaction

\section{Introduction}

Periradicular infections often contribute to the failure of endodontic treatment. [1] Enterococci is the predominant microorganism in the root canal, which is gram-positive and facultative anaerobe [2] and majorly responsible for perioapical lesions. About $77 \%$ of persistent endodontic infections are asymptomatic [2-6] and possess certain virulent factors like proteolytic enzymes, cytolysin, aggregation substance, pheromones, and lipoteichoic acid. They have a tendency for bonding to the root canal walls and forming a biofilm [7]. They survive a wide variety of growth conditions, including a temperature range of $10^{\circ} \mathrm{C}$ to $45^{\circ} \mathrm{C}$, and they also live in hypotonic, hypertonic, acidic, or alkaline environments [8] Various studies have shown that Enterococci are resistant to various intracanal treatment procedures [9]. This is attributed to their ability to penetrate dentinal tubules, withstand high $\mathrm{pH}$ values, possess virulence factors, and form biofilm [10]. Canal preparation does not completely eliminate the bacteria, but the application of canal medications can eliminate the persistent organisms following biomechanical preparation.

Mechanical preparation of the canal leads to disruption in the microbial configuration, whereas anti- 
microbial rinsing of the canal results in a reduction in the microbial load [11]. Herbal derivatives are a good alternative medicament having anti-microbial potent due to the amalgamation of alkaloids present in these mixtures [12]. This study highlights the efficacy of a herbal product as an intracanal medicament to overcome the cytotoxicity of polypotent stem cells. This study is done to evaluate the antibacterial efficacy of dried fruits of Piper nigrum (Piperaceae), Piper longum (Piperaceae), and rhizome of Zingiber officinale Roscoe (Zingiberaceae) extracts as an intracanal medicament against E. faecalis by using real-time polymerase chain reaction (PCR) tests [13].

\section{Materials And Methods \\ Preparation of the blocks}

Sixty freshly extracted non-carious, mandibular premolar teeth were selected for the study. Decoronation of the teeth was done with a rotary diamond disk and the middle third of the root was taken for the study purpose. The dentin blocks were standardized to its internal diameter to GG drill no.3 (Mani Inc, Tachigiken, Japan). The blocks were treated with $3 \%$ sodium hypochlorite for 10 minutes followed by $17 \%$ ethylene diamine tetraacetic acid for five minutes to remove the smear layer. The blocks were rinsed with $10 \mathrm{ml}$ distilled water to eliminate the residual irrigant solution and subjected to autoclave sterilization at $121^{\circ} \mathrm{C}$.

\section{Contamination of the dentin blocks}

The antibacterial activity of the test medicament was tested with a pure strain of Enterococcus faecalis using American Type Culture Collection and laminar flow method. Overnight, an incubated fresh culture of E. faecalis was grown in a brain heart infusion broth, incubated for 24 hours at $37^{\circ} \mathrm{C}$. One $\mathrm{ml}$ of inoculums was transferred to individual sterile microcentrifuge tubes containing $1 \mathrm{ml}$ of the respective broths and dentin block. After 48 hours, fresh broth containing microorganism was transferred to the tube containing dentin blocks.

\section{Anti-microbial assessment}

After the incubation period, $5 \mathrm{ml}$ of sterile saline was used as an irrigant to eliminate the broth medium. The dentin blocks were grouped as follows $(n=10)$ :

Group 1: Piper nigrum (Piperaceae) extract with methylcellulose

Group 2: Piper longum (Piperaceae) extract with methylcellulose

Group 3: Zingiberofficinale Roscoe (Zingiberaceae) extract with methylcellulose

Group 4: Calcium hydroxide

Group 5: 2\% chlorhexidine gel

Group 6: Untreated positive control

After treating with medication, all the blocks were covered with a sealant and placed in the aerobic incubator at $37^{\circ} \mathrm{C}$. After 24 hours, an antimicrobial assay was carried out with 10 blocks from each group. Using $5 \mathrm{ml}$ sterile saline, the blocks were washed. Dentin debris was harvested at a depth of 400 um by using GG drills no. 5, collected in $1 \mathrm{ml}$ of sterile PBS buffer solution, and subjected to aerobic incubation at 37C for 24 hours. Following this procedure, the samples were evaluated by real-time PCR.

\section{Results}

In the results, threshold cycles (Ct) were determined by PCR (Figure 1). The study revealed that $2 \%$ CHX has a greater antimicrobial effect, followed by $\mathrm{Ca}(\mathrm{OH})_{2}$ (Table 1). It also established that the antibacterial property of Zingiberofficinale Roscoe (Zingiberaceae) extract with methylcellulose was at a satisfactory level. It was calculated that the percentage of bacterial loads was reduced in comparison to saline that is used as a negative control. Table 2 showed the multiple comparison of the mean threshold cycle (Ct) among groups. Two percent chlorhexidine showed the best antibacterial efficacy followed by $\mathrm{Ca}(\mathrm{OH})_{2}$ and

Zingiberofficinale Roscoe extract with methylcellulose (Table 3). Table 4 shows the multiple comparison of the mean number of copies of bacteria (bacterial load) among groups. 


\section{Cureus}

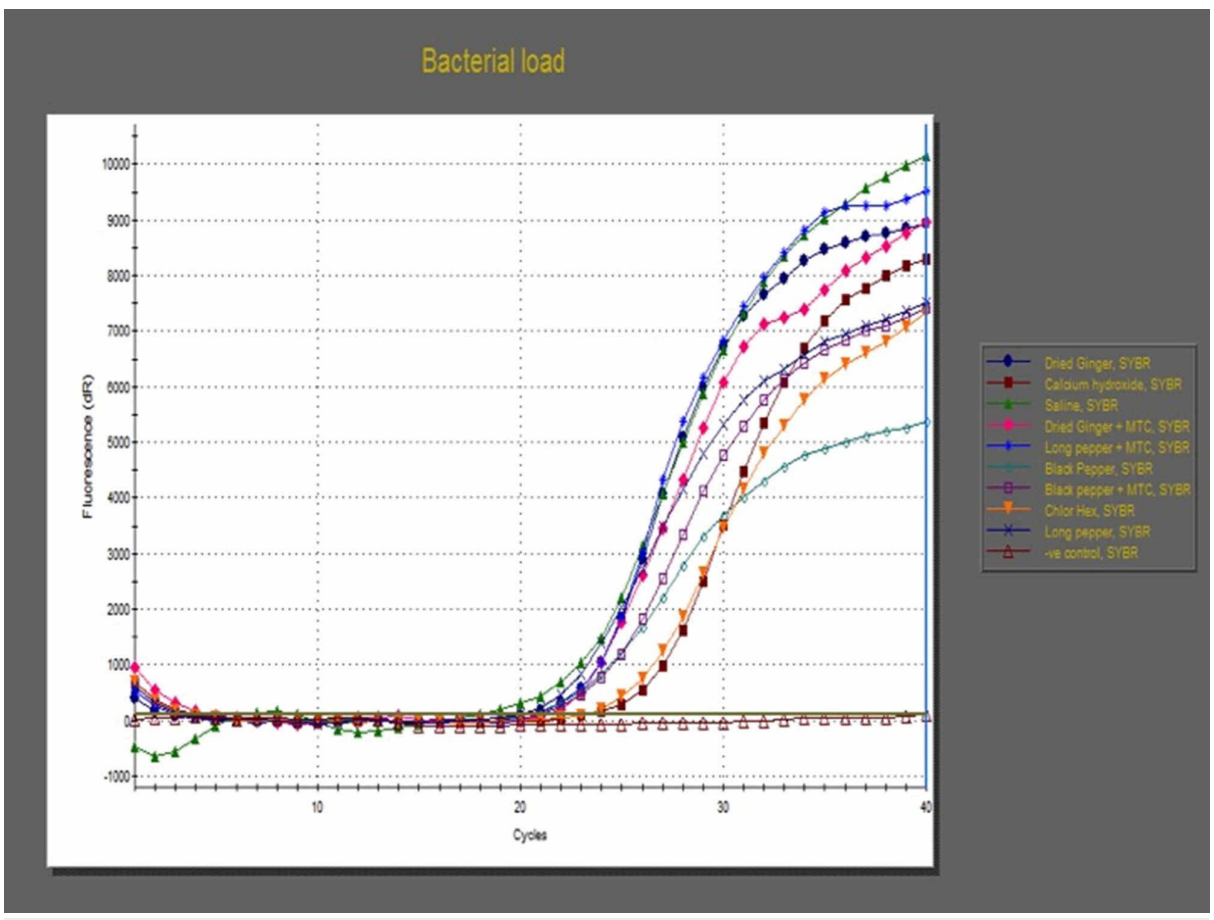

FIGURE 1: Quantitative real-time polymerase chain reaction (PCR) showing bacterial load

\begin{tabular}{|c|c|c|c|}
\hline Group & Mean \pm SD & F value & $p$-value \\
\hline Black Pepper with Methylcellulose & $21.369 \pm 0.250$ & \multirow{6}{*}{149.280} & \multirow{6}{*}{$0.000^{*}$} \\
\hline Long Pepper with Methylcellulose & $20.555 \pm 0.300$ & & \\
\hline Dried ginger with Methylcellulose & $22.148 \pm 0.509$ & & \\
\hline Calcium hydroxide & $22.512 \pm 0.330$ & & \\
\hline Chlorhexidine & $23.622 \pm 0.913$ & & \\
\hline Saline & $17.816 \pm 0.522$ & & \\
\hline
\end{tabular}

\section{TABLE 1: Comparison of mean threshold cycle (Ct) among the groups}




\section{Cureus}

\begin{tabular}{|c|c|c|}
\hline Groups & Mean difference & p-value \\
\hline Black Pepper with methylcellulose* Long Pepper with methylcellulose & 0.814 & $0.012 \#$ \\
\hline Long Pepper with methylcellulose* Dried Ginger with methylcellulose & -1.593 & $0.000 \#$ \\
\hline Dried Ginger with methylcellulose ${ }^{\star}$ Calcium Hydroxide & -0.364 & 0.627 \\
\hline Calcium Hydroxide ${ }^{\star}$ Chlorhexidine & -1.110 & $0.000 \#$ \\
\hline Chlorhexidine*Saline & 5.806 & $0.000 \#$ \\
\hline Saline*Black Pepper with methylcellulose & -3.553 & $0.000 \#$ \\
\hline Black Pepper with methyl cellulose*Dried Ginger with methylcellulose & -0.779 & $0.018 \#$ \\
\hline Black Pepper with methylcellulose*Calcium Hydroxide & -1.143 & $0.000 \#$ \\
\hline Black Pepper with methylcellulose ${ }^{*}$ Chlorhexidine & -2.253 & $0.000 \#$ \\
\hline Long Pepper with methylcellulose ${ }^{*}$ Calcium Hydroxide & -1.957 & $0.000 \#$ \\
\hline Long Pepper with methyl cellulose ${ }^{*}$ Chlorhexidine & -3.067 & $0.000 \#$ \\
\hline Long Pepper with methylcellulose*Saline & 2.739 & $0.000 \#$ \\
\hline Dried ginger with methylcellulose ${ }^{\star}$ Chlorhexidine & -1.474 & $0.000 \#$ \\
\hline Dried ginger with methylcellulose ${ }^{\star}$ Saline & 4.332 & $0.000 \#$ \\
\hline Calcium Hydroxide*Saline & 4.696 & $0.000 \#$ \\
\hline
\end{tabular}

\section{TABLE 2: Multiple comparison of mean threshold cycle (Ct) among groups}

\#Tukey's honestly significant difference (HSD), p $<0.05$

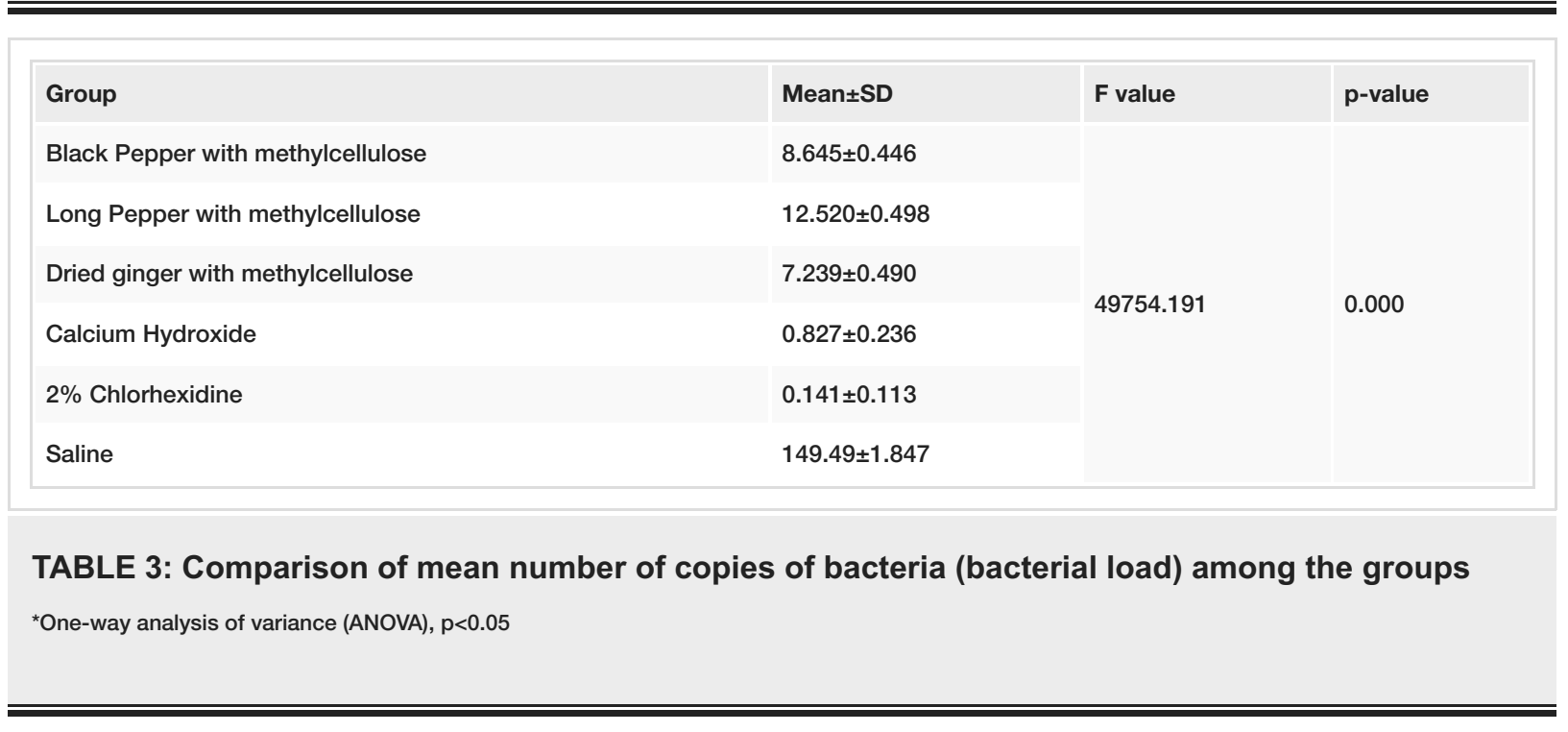




\section{Cureus}

\begin{tabular}{|c|c|c|}
\hline Group & Mean difference & p-value \\
\hline Black Pepper with methylcellulose` Long Pepper with methylcellulose & -3.875 & $0.000 \#$ \\
\hline Long Pepper with methylcellulose ${ }^{x}$ Dried ginger with methylcellulose & 5.280 & $0.000 \#$ \\
\hline Dried ginger with methylcellulose ${ }^{\star}$ Calcium Hydroxide & 6.412 & $0.000 \#$ \\
\hline 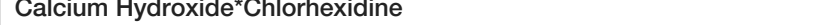 & 0.685 & 0.450 \\
\hline Chlorhexidine Saline & -149.35 & 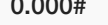 \\
\hline Saline*Black Pepper with methylcellulose & 140.85 & $0.000 \#$ \\
\hline Black Pepper with methylcellulose*Dried ginger with methylcellulose & 1.405 & $0.005 \#$ \\
\hline Black Pepper with methylcellulose ${ }^{*}$ Calcium Hydroxide & 7.817 & $0.000 \#$ \\
\hline Black Pepper with methylcellulose ${ }^{\star}$ Chlorhexidine & 8.503 & $0.000 \#$ \\
\hline Long Pepper with methylcellulose*Calcium Hydroxide & 11.692 & $0.000 \#$ \\
\hline Long Pepper with methylcellulose ${ }^{*}$ Chlorhexidine & 12.378 & $0.000 \#$ \\
\hline Long Pepper with methylcellulose*Saline & -136.97 & $0.000 \#$ \\
\hline Dried ginger with methylcellulose ${ }^{\star}$ Chlorhexidine & 7.098 & $0.000 \#$ \\
\hline Dried ginger with methylcellulose*Saline & -142.25 & $0.000 \#$ \\
\hline Calcium Hydroxide ${ }^{\star}$ Saline & -148.66 & $0.000 \#$ \\
\hline \multicolumn{3}{|c|}{$\begin{array}{l}\text { TABLE 4: Multiple comparison of mean number of copies of bacteria (bacterial load) among } \\
\text { groups }\end{array}$} \\
\hline \#Tukey's honestly significant difference (HSD), $\mathrm{p}<0.05$ & & \\
\hline
\end{tabular}

\section{Discussion}

Endodontic treatment success relies on the complete excavation of infective bacteria from the root canal space [14]. The endodontic infection mainly comprises the ecology of different microbial species. Proper cleaning and shaping of the root canal space will eliminate microbial populations [15].

E. faecalis is the most common pathogen associated with both primary and secondary endodontic infections [2-6]. There are various factors involving in the localization of microbes in the host such as oxygen, nutrient supply, bacterial synergism, etc.

E. faecalis form a biofilm, which in turn helps the bacteria to be more resistant towards microbial destruction. Contributing factors to resistance include the impenetrable polysaccharide coating on the biofilm bacteria, and these biofilm bacteria survive without dividing. Various physical factors that favor bacterial growth, which includes $\mathrm{pH}$, ion concentration, nutrient availability, and oxygen supply, vary throughout the biofilm [16].

The main use of an intracanal medicament is to destroy the bacteria that remains even after biomechanics preparation, thereby providing a microbe-free environment. Intracanal medicaments have been used to disinfect root canals. The disinfectants used in the intracanal are camphorated monochlorophenol, formocresol, glutaraldehyde, and halides, as well as other material, including calcium hydroxide $(\mathrm{Ca}(\mathrm{OH}))$ and a few antibiotics [17].

The high $\mathrm{pH}$ (11-12.5) of $\mathrm{Ca}(\mathrm{OH})$ has antimicrobial properties and its dissociation into highly interactive and lethal hydroxyl ions destroys the bacterial cells through protein denaturation and cytoplasmic membrane and DNA disruption. Calcium hydroxide plays a major role in preventing bacterial reinfection by denying the nutrient supply and thus delaying recontamination [18].

The CHX gel has antimicrobial activity for up to 21 days after contamination. The interaction of the positively charged $\mathrm{CHX}$ molecules and the negative phosphate ions on the bacterial cell walls leads to the altered osmotic equilibrium of the bacterial cells. This, in turn, increases cell wall diffusion, thereby allowing the CHX molecule to penetrate the bacterial cell. 
The purpose of this study is to analyze the antimicrobial property of herbal products and compare it with that of the synthetic antimicrobial agents used as canal medicaments in endodontics. This will lessen the antibiotic resistance as well as provide cost-effective, biocompatibility, and non-toxic benefits.

Piper nigrum (Piperaceae) extract with methylcellulose, Piper longum (Piperaceae) extract with methylcellulose, and Zingiberofficinale Roscoe (Zingiberaceae) extract with methylcellulose are the herbal products used for the study. The study results revealed the better antibacterial efficacy of $2 \% \mathrm{CHX}$ with $\mathrm{Ca}(\mathrm{OH})_{2}$ and dried ginger when combined with methylcellulose as a base. Two percent CHX is a bactericidal medicament having the ability to diffuse through the dentinal tubules. Gingerol is the major active ingredient of ginger and is responsible for the antimicrobial properties.

The advantage of real-time quantitative PCR lies in discriminating and quantifying live and dead bacteria in the samples. This leads us to consider its application to be of great importance in identifying vulnerable bacteria. Real-time quantitative PCR is very sophisticated and identifies various microbial species and their strains.

\section{Conclusions}

Based on this study, we conclude that $2 \%$ chlorhexidine has greater antibacterial efficacy against E. faecalis and Zingiberofficinale Roscoe (Zingiberaceae) extract. Methylcellulose base also possesses similar antibacterial activity against $\mathrm{E}$. faecalis and can be considered for use as a canal medicament in endodontic practice. However in-vivo studies are essential to validate the results.

\section{Additional Information \\ Disclosures}

Human subjects: All authors have confirmed that this study did not involve human participants or tissue. Animal subjects: All authors have confirmed that this study did not involve animal subjects or tissue. Conflicts of interest: In compliance with the ICMJE uniform disclosure form, all authors declare the following: Payment/services info: All authors have declared that no financial support was received from any organization for the submitted work. Financial relationships: All authors have declared that they have no financial relationships at present or within the previous three years with any organizations that might have an interest in the submitted work. Other relationships: All authors have declared that there are no other relationships or activities that could appear to have influenced the submitted work.

\section{References}

1. RôçasIN, SiqueiraJF, Santos KRN: Association of Enterococcus faecalis with different forms of periradicular diseases. J Endod. 2004, 30:315-320. DOI:10.1097/00004770-200405000-00004

2. Molander A, Reit C, Dahlen G, Kvist T: Microbiological status of root-filled teeth with apical periodontitis . Int Endod J. 1998, 31:1-7.

3. Sundqvist G, Figdor D, Persson S, Sjogren U: Microbiologic analysis of teeth with failed endodontic treatment and the outcome of conservative re-treatment. Oral Surg Oral Med Oral Pathol Oral Radiol Endod. 1998, 85:86-93.

4. Hancock HH, Sigurdsson A, Trope M, Moiseiwitsch J: Bacteria isolated after unsuccessful endodontic treatment in a North American population. Oral Surg Oral Med Oral Pathol Oral Radiol Endod. 2001, 91:579-586. 10.1067/moe.2001.113587

5. Stuart CH, Schwartz SA, Beeson TJ, Owatz CB: Enterococcus faecalis: its role in root canal treatment failure and current concepts in retreatment. J Endod. 2006, 32:93-98. 10.1016/j.joen.2005.10.049

6. Pinheiro ET, Gomes BPFA, Ferraz CCR, Sousa ELR, Teixeira FB, Souza Filho FJ: Microorganisms from canals of root-filled teeth with periapical lesions. Int Endod J. 2003, 36:1-11.

7. Jhajharia K, Mehta L, Parolia A, Shetty K: Biofilm in endodontics: a review . J Int Soc Prevent Communit Dent. 2015, 5:1-12. 10.4103/2231-0762.151956

8. Gilmore MS: The Enterococci: pathogenesis, molecular biology, and antibiotic resistance. ASM Press, Washington: DC; 2002.

9. Svensater G, Bergenholtz G: Biofilms in endodontic infections. Endod Topics. 2004, 9:27-36.

10. Kandaswamy E, Nagendrababu V, Kalaiselvam R, Deivanayagam K: Dentinal tubule disinfection with $2 \%$ chlorhexidine, garlic extract, and calcium hydroxide against Enterococcus faecalis by using real-time polymerase chain reaction: in vitro study. J Conserv Dent. 2013, 16:194-198.

11. Gupta A, Duhan J, Tewari S, et al.: Comparative evaluation of antimicrobial efficacy of Syzygium aromaticum, Ocimum sanctum and Cinnamomum zeylanicum plant extracts against Enterococcus faecalis: a preliminary study. Int Endod J. 2013, 46:775-783. 10.1111/iej.12058. Epub 2013 Mar 18

12. Baumgartner JC, Siqueira JF Jr, Xia T, Rôças IN: Geographical differences in bacteria detected in endodontic infections using polymerase chain reaction. J Endod. 2004, 30:4-10. DOI:10.1097/00004770-20040300000004

13. Zehnder M: Root canal irrigants. J Endod. 2006, 31:389-398. 10.1016/j.joen.2005.09.014

14. Vinothkumar TS, Rubin MI, Balaji L, Kandaswamy D: In vitro evaluation of five herbal extracts as an antimicrobial endodontic irrigant using real time quantitative polymerase chain reaction. J Conserv Dent. 2013, 16:167-170. 10.4103/0972-0707.108208

15. Costerton JW, Stewart PS, Greenberg EP: Bacterial biofilms: a common cause of persistent infections . Science. 1999, 284:1318-1322. 10.1126/science.284.5418.1318 


\section{Cureus}

16. Orstavik D, Haapasalo M: Disinfection by endodontic irrigants and dressings of experimentally infected dentinal tubules. Endod Dent Traumatol. 1990, 6:142-149.

17. Stuart KG, Miller CH, Brown CE Jr, Newton CW: The comparative antimicrobial effect of calcium hydroxide . Oral Surg Oral Med Oral Pathol. 1991, 72:101-104.

18. Kim D, Kim E: Antimicrobial effect of calcium hydroxide as an intracanal medicament in root canal treatment: a literature review - part II.in vivo studies. Restor Dent Endod. 2015, 40:97-103. 10.5395/rde.2015.40.2.97 